\title{
Social and Emotional Intelligence in School Environment
}

\author{
PaedDr. Zuzana Birknerová, PhD. \\ Department of Managerial Psychology, Faculty of Management \\ University of Prešov in Prešov, Konštantínova 16, 08001 Prešov, Slovakia \\ E-mail: zbirknerova@unipo.sk
}

$\begin{array}{lrr}\text { Received: April 19, } 2011 & \text { Accepted: June 7, } 2011 & \text { Published: October 1, } 2011 \\ \text { doi:10.5539/ass.v7n10p241 } & \text { URL: http://dx.doi.org/10.5539/ass.v7n10p241 }\end{array}$

The research is financed by Grant - VEGA 1/0831/10: "Social intelligence and perception of a teacher in the school social context"

\begin{abstract}
The article focuses on the problem of social and emotional intelligence in school environment, as this aspect of social psychology has never been researched in detail from the pedagogical viewpoint. The main objectives of the research were to find out whether headmasters, teachers and students are socially and emotionally skilled, whether social and emotional intelligence are viewed differently according to gender and whether there are any connections between the mentioned aspects and the age of respondents. In the first part of the analysis we tried to find differences between the position within an organisation and social and emotional intelligence. The second part focuses on the differences between gender and social and emotional intelligence. The third part describes the connections between the age of respondents and social and emotional intelligence. The research was carried out by means of the TSIS and TEIQue-SF questionnaires on the sample of 569 participants.
\end{abstract}

Keywords: Social intelligence, Emotional intelligence, School environment

\section{Social intelligence}

When predicting and interpreting human behaviour, a specific area is created by interpersonal situations and behaving of a person in such situations, in other words, managing and solving problems where an important role is played by the factor of social contacts of people. One of the significant characteristics used when describing and predicting such behaviour is social intelligence. An increase in professional interest in the broad issue of social intelligence can be observed in the period of the second half of the 20th century. A dramatic increase of reports involving this issue has been recorded in the last 30 years. Although social intelligence is a real individual characteristic (Silvera, et al., 2001) and the beginning of efforts to measure it date back to Thornedike (Kihlstrom, Cantor, 2000), when trying to distinguish it more precisely we encounter certain difficulties (Silvera, Martinussen, Dahl, 2001). One of the reasons for these difficulties is connected with distinguishing social intelligence from other similar constructs, such as academic intelligence, emotional intelligence or practical intelligence. When defining social intelligence we emphasize how individuals understand and interpret their own behaviour and behaviour of other people, and also, depending on this interpretation, how they can effectively regulate their behaviour. Developing social intelligent behaviour of an individual predicts improvement of self-reflection, reflection of social processes, reflection of the subjective sense and interpretation of behaviour, social competence training (Orosová, et al., 2004). When defining social intelligence, various components are emphasized. Some definitions accentuate rather perception, cognitive-analytical dimension, or an ability to understand other people (eg. Barnes, Sternberg, 1989). Other definitions concentrate more on behaviour, or an ability to successfully affect other people (eg. Ford, Tisak, 1983), and emphasize rather behavioural aspect. Social intelligence is characterized also from the point of view of the classic three-component model with differentiation of perception, cognitive, and behavioural components (Bjorkqvist, 2000). Multidimensional feature of the social intelligence construct is unquestionable. At the same time, as it was noted by Silvera, Martinussen and Dahl (2001), some of its dimensions are closely connected to academic intelligence, others more to personal features. As we observe basic lines of social intelligence study in literature, essentially, two main tendencies represented by psychometric or personal approach (Kihlstrom, Cantor, 2000) can be set apart. 
The psychometric approach conceptualizes and operationalizes social intelligence as an ability or a number of abilities, where people can be compared on a low versus high dimension, and in this case the only difference from the academic intelligence study is in focus on the social sphere (Silvera, et al., 2001). On the other hand, personal approach representatives speculate about social intelligence on the basis of behaviour in various interpersonal situations, social interactions, and social structures (Ruisel, 1999), which are not evaluated strictly on the efficiency dimension. A considerable attention is paid on the aspect of subjective view on social intelligence. In these connections, social intelligence is perceived as a personality feature, and one of the possible approaches to its examination and determination is the behavioural situational concept (Frankovský, Štefko, Baumgartner, 2006; Baumgartner, Frankovský, 2004).

Social-personality approach in the study of intelligence is according to Ruisel (1999) orientated on the outer world of social interactions and social structures, on the role behaviour in social systems, and on maintaining and development of human relations. The study of the personality structure can be performed in two ways of approaching the problem:

- an approach that presumes the existence of internal rules and connections between given properties

- an approach that is based on the opinion that features are not organized and investigation of the personality structure consists of making a complete list of personality features.

Social intelligence is charged neutrally; it is a construct which can be used in the pro-social, as well as the anti-social context. Requirements of the situation and personality aspects determine goals, in the name of which, in order to reach them, individuals may use their social intelligence (Kaukiainen, et al., 1995). Silvera, Martinussen, and Dahl (2001) state that social intelligence consists of the following components: perceptibility of internal conditions and moods of other people, general ability to deal with other people, knowledge of social norms and social life, ability to orientate oneself in social situations, use of social techniques that enable manipulation, negotiating with other people, social charm and social adaptation. Social intelligence belongs to the competences that distinguish workers with a different performance; for example, self-realization, social realization, and managing relations. Social competences and the ability to communicate and lead people should be an essential part of every manager's equipage.

\section{Emotional intelligence}

The concept of emotional intelligence is very close to comprehension of social intelligence. According to Porvazník (2007) emotional intelligence is connected with qualities of the person, their character, temperament, perceptive, creative and physical (somatic) dispositions. Schulze, Roberts (2007) understand emotional intelligence as psychometric range of intuitively attractive idea that people differ in their emotional skills and that these differences reflect in their real lives. Bar-On et al. (2003) defined emotional intelligence as complex of emotional and social competence and skills, which help to put up with everyday troubles and to be more efficient in both personal and social life.

Salopek (2004) says that Daniel Goleman (1997) in his book "Emotional intelligence: Why it can matter more than IQ" brought emotional intelligence to top of mind and top of marketplace. Emotional intelligence is also back in the news and enjoying renewed credibility. A new study shows that business leaders rank emotional intelligence competences as more important than traditional leadership attributes to leadership success. Also in Goleman's study "What makes a successful leader" participants were asked to evaluate a set of standard leadership attributes, including emotional intelligence (such as relationship building and self-awareness) and traditional leadership attributes (such as execution and financial acumen). Here are the significant findings:

- vision topped the list of critical leadership competences across nearly all levels, experience, and personality types; also ranked in the top five are strategic thinking, relationship building, execution, and people development;

- emotional intelligence attributes are viewed as essential to successful leadership, especially the complex capabilities of vision, relationship building, and people development;

- of the remaining attributes, leaders rated all of the EI competences - including adaptability, optimism, empathy, and self-awareness - as more important than all other general leadership attributes presented.

Emotional intelligence comes from fulfilling conditions of seven problematic fields: self-awareness, self-motivation, persistence, control of impulses, regulation of moods, empathy, hope or optimism. Five wider types of abilities important for emotional intelligence according to Gardner (1993) are:

- Knowing own emotions - self-awareness; people who are more sure of their feelings can make better 
decisions in their lives.

- Handling of emotions - working with the emotions in responsive way; people who lack this ability feel anxious moments quite often, those who excel here can recover faster from shocks and disappointments in life.

- Ability to self-motivation - emotional self-control: putting off rewards or satisfaction, along with suppressing excitable actions, is the essence for being successful.

- Empathy - as a basic human quality; empathic people are tuned in to react to others' wishes and needs. That is why they excel in professions where they can "care" for someone, like teaching, management, or marketing.

- The art of interpersonal relationships - to be empathic and act in such way, this art is in the background of popularity, dominant position or ability to constructive dealing with people.

Each of our emotional qualities is to considerable extent created by some habit - when we make an effort, we can change our reactions for better. Emotional competence is achieved through the leader's approach to their own personality, improving of interpersonal skills and it results in professional and personal success; this begins with empathy. A person must know their own self, their own motives and aims, values, feelings and way of thinking only afterwards they can make decisions more freely and purposefully. Right choice and good performance in emotionally demanding conditions characterize success. The tool for harmonizing is creation, such skills as self-motivation, self-discipline, relationships building and empathy. Socially competent person is someone who is able to build relationships without problems, who skillfully recognizes reactions and feelings of people, someone who belongs among leaders and organisers - it is the type of person with whom people feel comfortable because he/she spreads good humour (Birknerová, 2010).

Social interactions in everyday life and relationships are based mainly on social and emotional intelligence their improvement can prevent from existence of many conflicts (Vavrová, 2009). Well-developed socio-psychological competences, according to Jurková, Ferencová (2010), accelerate adaptation to concrete environment and enable active working. Holková, Gyurák Babel'ová, Vaňová (2008) agree with opinion that development of these competences depend on level of ability to absorb new knowledge and put them into practice. According to Droppa (2008) development of an individual requires careful study of the surroundings; interpersonal qualities and study of opinions of others, effort to understand them, support for mutual bonds, teambuilding, orientation to further development and helping others in their development consists mainly in education, as well as development of other social-emotional competence.

\section{Research}

The main aim of the research was to discover connections between social and emotional intelligence of our respondents, in relation to their position in organisation, gender and age. Emotional intelligence was measured by TEIQue-SF questionnaire (Petrides, Furnham, 2006) and social intelligence was measured by TSIS (Silvera, Martinussen, Dahl, 2001) questionnaire.

The target group made 297 teachers, 157 headmasters and 115 students. The research sample represented 569 respondents, where women $(\mathrm{N}=414,72.76 \%)$ had bigger representation than men $(\mathrm{N}=155,27.24 \%)$. The average age of respondents was 27.82; the youngest respondent was 18 years old and the oldest was 55 years old. The collecting of data was being made from January to October 2010. The results were worked out in SPSS statistic programme.

\subsection{Research method}

For purposes of our research we used two methodologies: TSIS and TEIQue-SF.

TSIS: In the context of solving the given objectives and questions we also used a social intelligence methodology TSIS - Tromso Social Intelligence Scale (Silvera, Martinussen, Dahl, 2001). TSIS consists of 21 self-evaluation items, which are answered by respondents on a 7-point scale of agreement degree $(1-$ describes me extremely poorly, 7 - describes me extremely well). The questionnaire is divided into three subscales and enables to specify 3 factors:

$\mathrm{SP}$ - social information processing (e.g. I can predict how others will react to my behaviour.)

SS - social skills (e.g. I am good at entering new situations and meeting people for the first time.)

SA - social awareness (e.g. I am often surprised by others' reactions to what I do.).

The internal validity of these factors are presented as follows: SP -0.79 , SS -0.85 , and SA -0.72 (Silvera, 
Martinussen, Dahl, 2001). The scale factors statistically correlate. The research of Makovská, Kentoš (2006) demonstrates the satisfying level of reliability of the TSIS.

TEIQue-SF: TEIQue-SF, shortened form, consists of longer form of TEIQue (Petrides, Furnham, 2003) and includes 30 items representing 7-points Likert scale, where 1 means I completely disagree and 7 means I completely agree. For each question there are 2 of 15 subscales, which were chosen from TEIQue for integration, and based especially on their correlation with the whole subscales score. The model of emotional intelligence successfully integrates and broadens the connected thoughts on emotional intelligence in general scope consisting of 15 concrete specific aspects: adaptability, control of emotions, low impulsivity, self-motivation, the feature of empathy, assertiveness, expressing emotions, relationships, social awareness, the feature of happiness, emotional appreciation, handling of emotions of others, self-respect, coping with stress, the feature of optimism. TEIQue evaluates all above mentioned aspects on 15 subscales. Besides that it provides score on 4 factors of wider importance: satisfaction, self-control, emotiveness and social behaviour. It is important to keep realizing that the results do not reflect cognitive abilities (e.g. IQ), but more self-perceptive abilities and relations disposals.

\subsection{Results and interpretations}

By research we tried to find out connections between social and emotional intelligence in relation to position in organisation, gender and age.

\subsubsection{Position in organisation}

In the first part of the analysis we tried to find the differences between position in organisation and subscales of social intelligence, as well as between aspects and factors of emotional intelligence. We used Post-hoc comparison for this purpose. Statistically significant differences were discovered between position in organisation and EQ aspects: self-respect (Table 1), low impulsivity (Table 2), adaptability (Table 3) and factor of self-control (Table 4). Statistically significant differences were not discovered between subscales of social intelligence and position in organisation.

On the basis of analysis of dispersion $\mathrm{F}=3.069$, Sig. $=0.048$ we discovered significant differences in EQ aspect of self-respect, in relation to position in organisation.

Table 1 shows that statistically significant differences in aspect of self-respect exist between headmasters and teachers, as well as between headmasters and students, always to headmasters' advantage. The addressed headmasters know their own value, they have enough self-confidence and respect for their own personality. Generally, they can evaluate their own merits. We also detected significant differences in EQ aspect of low impulsivity, in relation to position in organisation on the basis of analysis of dispersion $\mathrm{F}=9.684$, Sig $=0.000$.

In Table 2 it can be seen that in the EQ aspect of low impulsivity there are statistically significant differences between students and teachers and also between students and headmasters, always to students' disadvantage. Students seem to behave more impulsively than teachers and headmasters.

On the basis of analysis of dispersion $\mathrm{F}=3.620$, Sig. $=0.028$ we also discovered significant differences in $\mathrm{EQ}$ aspect of adaptability, in relation to position in organisation.

Table 3 demonstrates the statistic significance between students and teachers and also between students and headmasters in EQ aspect of adaptability, always to students' disadvantage. In this aspect of EQ, students can least adopt to existing situations and their surroundings.

On the basis of analysis of dispersion $\mathrm{F}=3.443$, Sig. $=0.048$, significant differences have been discovered also in EQ factor of self-control in relation to position in organisation.

Self-control (Table 4) is the basic condition for achieving desired result. Teachers we addressed have a high level of this factor in comparison to students. The students should realize that people with insufficient self-control not only do not have their emotions under control, but also they cannot be perceptive to emotions of others. A person who has the ability to self-control tries to respond to stimuli properly, with regard to probable answer from others.

\subsubsection{Gender}

In the second part of the analysis we tried to find the differences between gender and subscales of social intelligence, as well as between aspects and factors of emotional intelligence. We used t-tests for this purpose. Statistically significant differences (Table 5) were discovered between age and aspects of EQ: control of emotions, self-motivation, coping with stress, low impulsivity, assertiveness, relationships, adaptability. We discovered statistic significance between gender and factors of EQ: self-control, social behaviour. Statistic 
significance was not detected between factors of social intelligence and gender.

All mentioned aspects and factors of emotional intelligence are statistically significant always to advantage of the addressed males. Knowing own emotions means knowingly discern emotions in the moment of their occurrence. When we realize our emotions, it does not mean we are not defenseless. Males who are more aware of their emotions can make better decisions because they know what influenced them - they make their decisions more carefully and stick to them more closely. Males are also, unlike females, more assertive in their behaviour and can handle stressful situations better.

\subsubsection{Age}

In the third part of the analysis we tried to find the connections between the age of respondents and subscales of social intelligence, as well as between aspects and factors of emotional intelligence. We used Pearson correlation coefficient for this purpose. Statistically significant connections are presented in Table 6.

We discovered connections between the age of the respondents and subscale of social intelligence - social awareness. Negative correlation shows that with increasing age the sensitivity for perception and deciphering of social signals descends. Negative correlation can also be seen between the age and aspects of EQ: self-respect and assertiveness, which also descend with increasing age. Positive correlation exists between the age and aspects of EQ coping with stress and low impulsivity. Older respondents cope with stress more easily and they are also less impulsive than younger respondents. Factor EQ of self-control is in positive relation to the age of respondents. Older respondents have their emotions under control and can be perceptive to emotions of others.

\section{Conclusion}

The aim of the presented research was to find the answer to the question whether headmasters are socially and emotionally competent, and to compare them with teachers and students. Our intention was also to detect differences between perception of social and emotional intelligence between males and females, as well as among respondents in relation to their age.

Social and emotional competence create our character, they enable us to understand our personal and interpersonal feelings and relationships. The intrapersonal part of emotional intelligence is responsible for our ability to feel positive or negative emotions and command their outward displays. We set the aims, we solve problems or we face obstacles standing in our way. Interpersonal development includes our relationships with other people, social abilities, such as empathy, acceptance of the opinions of others and the ability to live, work and cooperate with others.

The art of relationships consists in creation and keeping satisfactory relationships, in being adoptable. This is the substance for popularity, dominant position and abilities for constructive working with people. People who are strong in this field are social stars, they can cooperate very well with others. These are the people with whom we feel emotionally well. These people are popular, charming, they can calm down negative emotions of others - we seek their company in time of distress or when there is some conflict going.

The higher we go in company's hierarchy, the more important the emotional intelligence is. It creates from 85 to $90 \%$ of working profile of top managers. Emotional intelligence means intelligent handling of our emotions communication with people from different cultures, developing sense for unwritten rules and ability to adapt to them. The addressed headmasters seem to be self-confident people with high level of self-respect - unlike students, who have low level of self-control and adaptability. Teachers are distinguished mainly by low impulsivity.

Unlike IQ, which is congenital, emotional competence can be improved in each age. We can learn conviction, team-work or self-confidence by training, e.g. when we want to learn something from emotional competence, we must learn from models, practice and repetition. Emotional competence can be developed mainly by young people, in this case students. Here, Račková (2010) presents the possibility of active work on seminars or lessons, using some innovation form. Ali Taha, Tej (2010) see advantages of such work with students in learning to cooperate with others, developing their creativity, self-assessment and other social-emotional competence necessary for their future profession.

The addressed teachers seem to be successful in stimulation of socio-emotional development of their students. They are able to understand their own selves, their virtues and insufficiencies, express their emotions and thoughts, as well as understand lives and needs of other people, particularly their students. They are also able to create and develop cooperative, constructive, and mutually satisfying relationships. Successful work of a teacher therefore also involves well-developed social intelligence. However, it is necessary to note that all teachers have their own individual qualities. That is why we will never be certain that the generalized conclusions about what brings 
success will be applicable in all cases.

\section{References}

Ali Taha, V., Tej, J. (2010). Nové prístupy vo vzdelávaní manažérov verejného sektora ako forma motivácie študentov. In Ekonomický a sociálny rozvoj Slovenska. Bratislava: VŠEMVS, 2010, s. 673-682.

Barnes, M. L., \& Sternberg, R. J. (1989). Social intelligence and decoding of nonverbal cues. Intelligence, 13, 263-287. http://dx.doi.org/10.1016/0160-2896(89)90022-6

Bar-On, R. (2003). How important is it to educate people to be emotionally and socially intelligent, and can it be done? Perspectives in Education, 21(4), 3-13.

Baumgartner, F., Frankovský, M. (2004). Possibilities of a situational approach to social intelligence research. Studia Psychologica, 46, 4, 273-277.

Birknerová, Z. (2010). Aspekty sociálnej a emocionálnej inteligencie v praxi. In Manažment podnikania a vecí verejných - dialógy. Bratislava: Slovenská akadémia manažmentu, o.z., č.12/2010, V. ročník, s.7-18.

Bjorkqvist, K., Osterman, K., \& Kaukiainen, A. (2000). Social Intelligence - Empathy = Aggression? Aggresion and Violent Behavior, 5, 2, 191-200. http://dx.doi.org/10.1016/S1359-1789(98)00029-9

Droppa, M. (2008). Riadenie l’udských zdrojov 1. Ružomberok: Katolícka univerzita v Ružomberku, Pedagogická fakulta, $130 \mathrm{~s}$.

Ford, M. E., \& Tisak, M. S. (1983). A further search for social intelligence. Journal of Education psychology, 75, 196-206. http://dx.doi.org/10.1037/0022-0663.75.2.196

Frankovský, M., Štefko, R., \& Baumgartner, F. (2006). Behavioral-situational approach to examinig social inteligence. Studia Psychologica, 48, 3, 251-258.

Gardner, H. (1993). Multiple intelligences: The theory in practice. New York: Basic Books, $440 \mathrm{~s}$.

Goleman, D. (1997). Emoční inteligence: Proč muže být emoční inteligence duležitejší než IQ. Praha: Columbus, $348 \mathrm{~s}$.

Holková, A., Gyurák Babel’ová, Z., Vaňová, J. (2008). Manažérske kompetencie. Research papers Faculty of Materials Science and Technology Slovak University of Technology in Trnava. č. 25, s. 57-61.

Jurková, J., Ferencová, M. (2010). The opportunities for increasing the marketing communication efficiency on the university education market. In Management 2010. (Part I.) Prešov: University of Prešov in Prešov, p. 435-443.

Kaukiainen, A., Bjorkqvist, K., Osterman, K., Lagerspetz, K, \& Forsblom, S. (1995). Peer-Estimated Social Intelligence (PESI). Turku, Finland: Department of Psychology, University of Turku.

Kihlstrom, J. F., \& Cantor, N. (2000). Social Intelligence. [Online] Available: http://ist-socrates.berkeley.edu/ kihlstrm/social_intelligence.htm.

Makovská, Z., \& Kentoš, M. (2006). Correlates of social and abstract intelligence. Studia Psychologica: an International Journal for Research and Theory in Psychological Sciences, vol. 48, no. 3, p. 259-264.

Orosová, O., et al. (2004). Sociálna inteligencia, sociálna kompetencia- definície a prístupy v ich skúmaní. Československá psychologie 2004, ročník XLVIII, číslo 4, s.306-315.

Petrides, K. V., Furnham, A. (2006). The role of trait emotional intelligence in a gender-specific model of organizational variables. Journal of Applied Social Psychology, 36, 552-569. http://dx.doi.org/10.1111/j.0021-9029.2006.00019.x

Porvazník, J. (2007). Celostný manažment, 3. prepracované a doplnené vydanie. Žilina: Poradca podnikatela, $540 \mathrm{~s}$.

Račková, M. (2010). Vybrané kapitoly zo psychológie. Abeceda psychológie pre technikov. Košice: TUKE, Katedra spoločenských vied, $123 \mathrm{~s}$.

Ruisel, I. (1999). Inteligencia a osobnost'. Bratislava: Veda, 239 s.

Salopek, J. J. (2004). Social Intelligence. Excerpted with permission from $T+D$ (Training \& Development), September. Provided by The Reprint Outsource, 717-394-7350.

Schulze, R., \& Roberts, R. D. (2007). Emoční inteligence. Přehled základních př́stupu a aplikací. Praha: Portál.

Silvera, D. H., Martinussen, M., \& Dahl, T. (2001). The Thomso Social Intelligence Scale, a self-report measure 
of Social Intelligence. Scandinavian Journal of Psychology, 42, 313-319. http://dx.doi.org/10.1111/1467-9450.00242

Vávrová, S. (2009). Význam emoční inteligence pro rozvoj kompetencí sociálního pedagóga. Sociální pedagogika ve středni Europě, současný stav a perspektívy. Brno: IMS, s. 600-608.

Table 1. Post-hoc comparisons of average values in EQ aspect self-respect according to position in organisation (Tukey HSD)

\begin{tabular}{|l|l|l|l|}
\hline $\begin{array}{l}\text { Position in } \\
\text { organisation }\end{array}$ & $\begin{array}{l}\text { Position in } \\
\text { organisation }\end{array}$ & $\begin{array}{l}\text { Mean } \\
\text { Difference }\end{array}$ & Sig. \\
\hline headmaster & teacher & 0.687 & $\mathbf{0 . 0 4 1}$ \\
\hline teacher & student & 0.233 & 0.417 \\
\hline student & headmaster & 0.920 & $\mathbf{0 . 0 1 1}$ \\
\hline
\end{tabular}

Table 2. Post-hoc comparisons of average values in EQ aspect of low impulsivity according to position in organisation (Tukey HSD)

\begin{tabular}{|l|l|l|l|}
\hline $\begin{array}{l}\text { Position in } \\
\text { organisation }\end{array}$ & $\begin{array}{l}\text { Position in } \\
\text { organisation }\end{array}$ & $\begin{array}{l}\text { Mean } \\
\text { Difference }\end{array}$ & Sig. \\
\hline headmaster & teacher & 0.263 & 0.484 \\
\hline teacher & student & 1.402 & $\mathbf{0 . 0 0 0}$ \\
\hline student & headmaster & 1.139 & $\mathbf{0 . 0 1 0}$ \\
\hline
\end{tabular}

Table 3. Post-hoc comparisons of average values in EQ aspect of adaptability according to position in organisation (Tukey HSD)

\begin{tabular}{|l|l|l|l|}
\hline $\begin{array}{l}\text { Position in } \\
\text { organisation }\end{array}$ & $\begin{array}{l}\text { Position in } \\
\text { organisation }\end{array}$ & $\begin{array}{l}\text { Mean } \\
\text { Difference }\end{array}$ & Sig. \\
\hline headmaster & teacher & 0.290 & 0.351 \\
\hline teacher & student & 0.626 & $\mathbf{0 . 0 3 7}$ \\
\hline student & headmaster & 0.977 & $\mathbf{0 . 0 1 0}$ \\
\hline
\end{tabular}

Table 4. Post-hoc comparisons of average values in EQ factor of self-control according to position in organisation (Tukey HSD)

\begin{tabular}{|l|l|l|l|}
\hline $\begin{array}{l}\text { Position in } \\
\text { organisation }\end{array}$ & $\begin{array}{l}\text { Position in } \\
\text { organisation }\end{array}$ & $\begin{array}{l}\text { Mean } \\
\text { Difference }\end{array}$ & Sig. \\
\hline headmaster & teacher & 0.438 & 0.619 \\
\hline teacher & student & 1.664 & $\mathbf{0 . 0 2 9}$ \\
\hline student & headmaster & 1.226 & 0.227 \\
\hline
\end{tabular}


Table 5. Statistic significance in the field of gender

\begin{tabular}{|c|c|c|c|c|c|}
\hline Emotional intelligence & Gender & Mean & $\begin{array}{l}\text { Std. } \\
\text { Deviation }\end{array}$ & $\mathbf{t}$ & Sig (2-tailed) \\
\hline \multirow{2}{*}{ Control of emotions } & male & 9.45 & 2.424 & \multirow{2}{*}{2.070} & \multirow{2}{*}{0.039} \\
\hline & female & 8.98 & 2.323 & & \\
\hline \multirow[t]{2}{*}{ Self-motivation } & male & 9.16 & 2.386 & \multirow{2}{*}{1.826} & \multirow{2}{*}{0.058} \\
\hline & female & 8.77 & 2.200 & & \\
\hline \multirow[t]{2}{*}{ Coping with stress } & male & 9.52 & 2.243 & \multirow{2}{*}{-2.736} & \multirow{2}{*}{0.006} \\
\hline & female & 8.92 & 2.321 & & \\
\hline \multirow[b]{2}{*}{ Low impulsivity } & male & 9.58 & 2.565 & \multirow{2}{*}{2.095} & \multirow{2}{*}{0.035} \\
\hline & female & 9.05 & 2.623 & & \\
\hline \multirow[t]{2}{*}{ Assertiveness } & male & 9.34 & 2.503 & \multirow{2}{*}{3.561} & \multirow{2}{*}{0.000} \\
\hline & female & 8.45 & 2.600 & & \\
\hline \multirow[t]{2}{*}{ Relationships } & male & 9.94 & 2.355 & \multirow{2}{*}{-2.241} & \multirow{2}{*}{0.039} \\
\hline & female & 9.49 & 2.211 & & \\
\hline \multirow[t]{2}{*}{ Adaptability } & male & 10.04 & 2.254 & \multirow{2}{*}{2.066} & \multirow{2}{*}{0.044} \\
\hline & female & 9.60 & 2.285 & & \\
\hline \multirow[b]{2}{*}{ Self-control } & male & 37.72 & 6.150 & \multirow[b]{2}{*}{3.444} & \multirow[b]{2}{*}{0.001} \\
\hline & female & 35.76 & 5.829 & & \\
\hline \multirow[b]{2}{*}{ Social behaviour } & male & 38.49 & 6.360 & \multirow{2}{*}{2.948} & \multirow{2}{*}{0.002} \\
\hline & female & 36.54 & 7.024 & & \\
\hline
\end{tabular}

Table 6. Connections between age and factors of SQ and EQ

\begin{tabular}{|l|l|l|l|l|l|l|}
\hline & $\begin{array}{l}\text { social } \\
\text { awareness } \\
\text { (SA) }\end{array}$ & self-respect & $\begin{array}{l}\text { coping } \\
\text { with stress }\end{array}$ & $\begin{array}{l}\text { low } \\
\text { impulsivity }\end{array}$ & assertiveness & self-control \\
\hline Age & $-.120^{* *}$ & $-.090^{*}$ & $.130^{* *}$ & $.150^{* *}$ & $-.094^{*}$ & $.143^{* *}$ \\
\hline
\end{tabular}

NB: Descriptions of the tables are included in the article. 